\title{
Using Zero Money to Tackle the Challenges of Universal Education in Africa: A Case of Universal Secondary Education in Uganda
}

\author{
Robert Agwot Komakech \\ Head of Department, Business Studies, Faculty of Social Sciences and Management Studies \\ Kumi University Kumi, Uganda (East Africa)
}

\begin{abstract}
Education is without a doubt, the sector that holds the key to transformational national development and our ability to compete in the global marketplace and it is singularly the sector that has experienced the worst type of decline in relation to standards, quality and value in Africa. However, the 1990 World Conference on Education for All launched in Jomtien, Thailand has rightly called attention to improving education through better management and expanded access to primary education systems with little attention to secondary education. Therefore, Government of Uganda through the Ministry of Education and Sports (MOES) with support from development partners introduced Universal Education in both primary and secondary schools throughout the country since 1997 and 2006 respectively. The intention was to remove barriers in education, provides flexible and responsive supports, and facilitates lifelong learning for all. Despite the fact that, the government continues to encourage families to send all their school going age children to Universal Secondary Education (USE) schools; the programme has not received the attention it deserves from either the public or the private sector in Uganda. Therefore, this theoretical paper seek to fill the existing long documented unequal academic achievement outcomes among children of different races, ethnic groups and social economic background in all regions of the country. This paper is organized in the following manner; Part I begins with a background and education systems of Uganda, while Part II discusses the major challenges the government is facing in enhancing access, quality and affordable education. Finally, Part III covers practical policy implications and Part IV gives concluding remarks with identified gaps for research.
\end{abstract}

Keywords: Zero Money, Universal Education, Secondary Education, Quality Education, Ghost Teachers

\section{BACKGROUND AND EDUCATION SYSTEMS OF UGANDA}

Formal education in Uganda began in the colonial period following a report in 1922 by the PhelpsStokes Fund. Prior to that report formal education was entirely in the hands of missionary organizations. The first commission was the de Bunsen Committee appointed in 1952, which recommended among other things: the expansion of secondary education in order to provide teachers for primary and junior secondary schools; expansion of facilities, both primary and secondary, for girls; and establishment of new primary schools. On October 09, 1962 Uganda became independent and the educational system consists of four levels of institutions, each followed by a national selection exam which feeds a centrally administered process of distributing successful candidates among the options available at the next level. Large numbers of students are forced out of the system at each transition stage because of limited capacity at the next level.

Primary education provides seven years of schooling which leads, for those who persist in the system to sit the Primary Leaving Examination (PLE). Successful candidates are admitted into four year secondary schools, as well as technical schools. Upon completion of the four years, candidates sit for national Uganda Certificate of Education (UCE), O-Level examinations. Depending on their results, candidates then have a choice of: proceeding to higher secondary school (A-Level); join a Primary Teacher College; enroll in a Technical Institute; or seek out a skill training option in the private sector for instance getting business skills. After two years in A-level secondary schools, candidates sit for the Uganda Advanced Certificate of Education (UACE) and successful candidates compete for places in the current seven (07) public universities or Thirty one (31) private Universities, the Institute of Teacher Education, Kyambogo; Uganda Colleges of Commerce; National Teachers Colleges or one of several Technical Training Institutions, (National Council for Higher Education, 2013; MoES, 1999). 


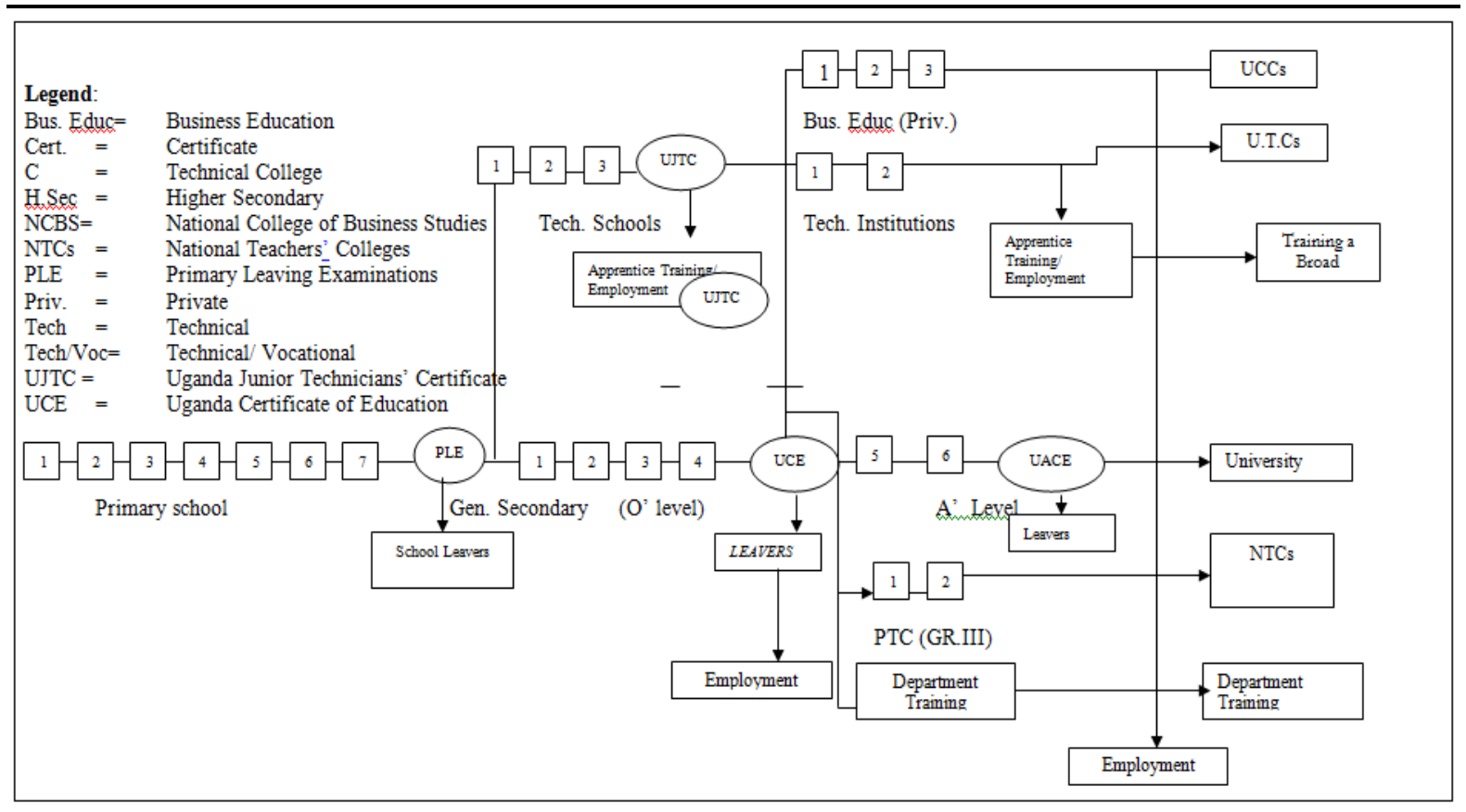

Figure1.1. Shows the Education Systems of Uganda Today

Source: MoES: Government White Paper on Education, 1992

The next commission was the Castle Commission appointed in 1963, less than a year after independence. The demand then was for high-level human power to take over the running and management of both the public and private sectors. The Ministry of Education and Sports in 1999 says, although the need for expanding primary education was recognized including Organization of African Union (OAU) currently known as African Union (AU) recommendation in 1961, it was felt that there were not enough resources for both the primary-levels and the higher levels. Therefore, a large proportion of the education budget then went to post-primary institutions for more than two decades. That situation persisted despite two attempts to promote universal primary education through the Third Five Year Development Plan (1972-1976) and the Education Policy Review Commission of 1977. The major constraint to achieving universal primary education was the negative political leadership of the time.

On taking power in 1986, the NRM government instituted a series of Commissions to investigate the situation in all areas of government. One of them was Education Policy Review Commission (EPRC), which was appointed in 1987 under the Chairpersonship of Professor W. Senteza Kajubi. Their terms of reference included, among other things, recommending policies at all levels of education (primary, secondary and tertiary). The EPRC met for two years and consulted widely with all stakeholders around the country. A major recommendation made by this commission was the Universalisation of Primary Education (UPE) in as near future as possible but not later than the year 2000. The commission defended their position in a way that: "Only when every child is enrolled at the right age and does not leave school without completing the full cycle of primary education it would be possible to ensure that all the citizens have the basic education needed for living a full life. Also it will help in achieving a transformation of the society leading to greater unity among the people, higher moral standards and an accelerated growth of the economy," Ministry of Education and Sport, 1999. Following the EPRC report, published in 1989 after consultations carried out nation-wide among all stakeholders, government appointed a White Paper Committee. This White Paper Committee was given the task to examine the EPRC report and identify the recommendations which were acceptable to government and feasible to implement and to make amendments where necessary. Government coopted 40 more people to carry out consultations as widely as possible. The Government White Paper was published in 1992. The White Paper accepted the major recommendation of the EPRC on primary education reform and with UPE only modified the time frame for completion of the programme to the year 2003.

In 1997, Universal Primary Education (UPE) was introduced following President Y.K. Museveni December, 1996 presidential pledge to the electorate to provide free primary education to four (4) 
children per family. The Ministry of Education and Sports, (1999) says the major objectives of the UPE programme were: To make basic education accessible to the learners and relevant to their needs as well as meeting national goals; Making education equitable in order to eliminate disparities and inequalities; Establishing, providing and maintaining quality education as the basis for promoting the necessary human resource development; Initiating a fundamental positive transformation of society in the social, economic and political fields; and, ensuring that education is affordable by the majority of Ugandans by providing, initially, the minimum necessary facilities and resources, and progressively the optimal facilities, to enable every child to enter and remain in school until they complete the primary education cycle. In order to achieve the above objectives, Government has ensured continued fulfillment of its obligations towards the education sector with special focus on the UPE programme. From the onset in 1997, Government committed itself to providing the following: tuition fees for four children per family at the rate of UShs. 5,000/= per pupil per annum for classes P1 to P3 and UShs. $8,100 /=$ per pupil per annum for classes P4 to P7; instructional materials in the form of text books; pay teachers salaries; and construction of basic physical facilities in form of classrooms, pit latrines, and teachers houses. This was to be by providing iron sheets, cement, timber and nails while local authorities and communities would make additional input especially in the form of labour for construction.

In 1997 following the introduction of UPE policy in Uganda, gross enrolment in primary schools increased from a total of 3.1 million in 1996 to 5.3 million in 1997, an increase of $73 \%$ in one year. This compares with an increase in gross primary school enrolment, in the decade preceding the introduction of UPE, of just 39\% (from 2.2 million in 1986). By 2003, gross enrolment in primary schools had reached 7.6 million and the national gross primary school enrolment ratio in 2003 was $127 \%$, indicating that children beyond standard primary-school age had rejoined the primary education cycle, (Ministry of Education and Sports, 2003). In FY 2013/2014; total enrolment increased by $0.3 \%$ from $8,459,720$ (4,219,523 boys; 4,240,197girls) in 2013 to 8,485,005 (4,235,669 boys; 4,249,336 girls) in 2014, (MoES: EMIS, 2014). On the other hand, during the last three decades, secondary schools have expanded significantly, although unevenly. Between 1970 and 2000, the number of secondary schools in Uganda increased from 73 to 1,892, and enrollment increased from about 50,000 to 518,931, a more than tenfold increase. The total number of secondary schools and enrollment was relatively flat during the 1970s, rising in the early 1980s, and then leveling out again until the mid-1990s. The pronounced growth in the number of institutions resumed in 1998, (World Bank, 2002; MoES, 2000).

Following the success of UPE policy, the Government of Uganda introduced free Universal Secondary Education (USE) policy in 2007. Since the introduction of USE, the programme saw the drastic increase in student enrolment (S1-S6) figures from 814,087 students in 2006 to 954,328, an increment of over 17.2\%; leading to increase in the transition rate from P7 to S1 by $22 \%$ from $46.9 \%$ to $68.6 \%$, (Ministry of Education and Sport, 2008). From 2007, the trend of enrolment has been steadily increasing with figures of 1,088,744, 1,194,454 and 1,225,692 for the years 2008, 2009 and 2010 respectively. The secondary subsector has also experienced steady improvement in schools response especially in privately run schools with the total number of schools increasing from 2,908, 3,149 and to 3,234 in the years 2008, 2009 and 2010 respectively, (Ministry of Education and Sport, 2010). Currently (2014), the total number of secondary schools increased from 2,793 (1,008 Government; 1,785 Private) in 2013 to 2,836 (1,016 government; 1,820 private) in 2014 while the number of secondary schools both government and private implementing USE program has also increased from 1,819 (944 government and 875 private) in 2013 to 1,822 (945 government; 877 private) in 2014 with students enrollment of 1,374,546 (709,140 boys and 665,406 girls) as compared to $1,362,739$ ( 727,212 boys; 635,527 girls) in 2013 showing the increase of $1 \%$ between 2013 and 2014. In addition, the number of classrooms in secondary schools also increased by $8 \%$ from 28,242 in 2013 to 30,459 in 2014, (MoES: EMIS, 2014). Although Uganda has experienced remarkable achievements in secondary education; Civil Society Organization, political leaders and the general public have continually equated the decline in the educational quality to budget constraint. This assertion is supported by the Ministry of Education and Sports 2014 report which contends that the share of Education and Sports Sector budget as a portion of the national budget has continued to decline despite the increasing demand for education services. The ministry emphasized that this has continued to impact critically on the implementation of various education policies. It is against this 
background that the researcher intends to fill the knowledge gap by providing the non-financial solutions to address the major challenges the government is facing in enhancing access, quality and affordable education in USE schools in Uganda.

\section{The Challenges Faced by Government in Enhancing ACCess, Quality and AFFORDABLE EDUCATION}

\subsection{Inadequate Funding}

Due to the limited funding, the sector budget has continued to fluctuate in the last decay from $12.63 \%$ in FY2003/2004 to $13.47 \%$ in 2014/2015 budget as shown in figure 1.2 below.

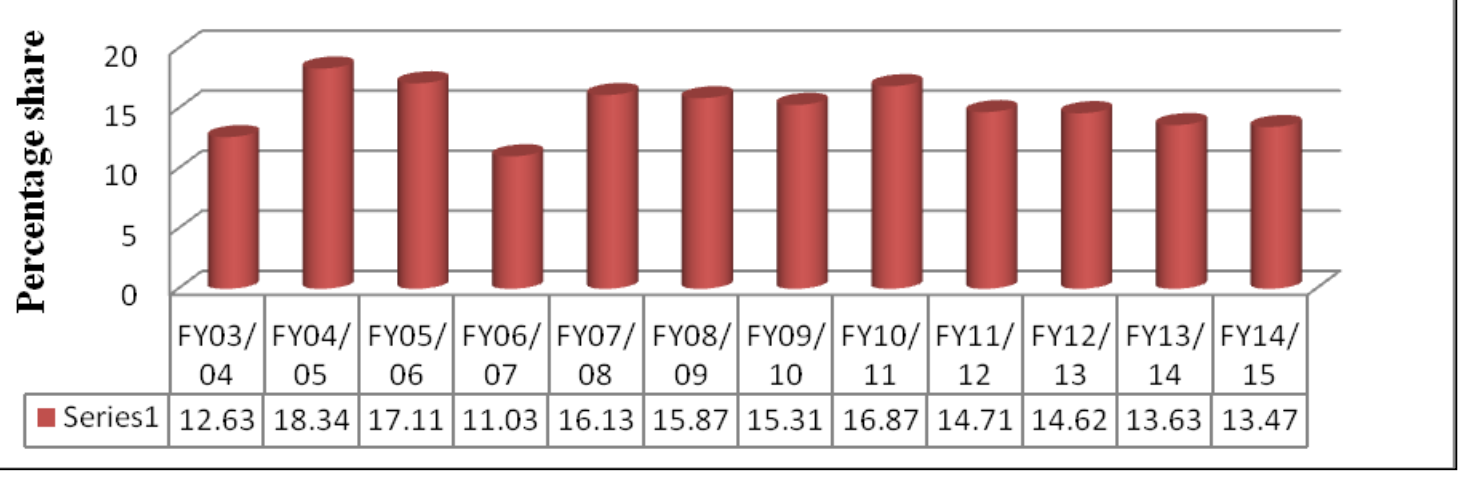

Figure1.2. Shows the Education Sector Budget Percentage Share of the National Budget From FY 2003/2004FY2014/2015

\section{Source: Reviewed by Researcher from MoES, EMIS 2014}

From the last five consecutive years, the graph shows the sector budget declined from $16.87 \%$ in FY 2010/2011 to $13.47 \%$ FY 2014/2015 indicating $20.15 \%$ budget decline. This budgetary constraint has negative impact not only on education access, affordability, but also on quality of education. According to the Teacher Utilization Study (2001) reveals that Secondary education unit costs are high because teachers on average teach only 22.5 periods per week out of a fifty period week. The average teacher spends less than 15 hours per week in the classroom and in total works about 29 hours per week and most under-utilized teachers teach only one subject of 45 percent of teachers teach only one subject. Similarly, in Uganda some schools have surplus teachers and these teachers teach only one or two periods in the week totaling to 04 hours for instance before 2015 teachers' transfer there was a school in Serere district which has five Geography and five Christian Region Education (CRE) teachers each teacher was teaching one class each since the school has only four classes that is S1-S4 with single streams. This implies that millions of budget allocation was spent on unproductive teachers making students and the government to lose at the same time protecting the low performing teachers in the school. For instance the school in question for the last ten years no student has got first grade in national examinations.

\subsection{High Teacher Turnover}

In the U.S, teachers are leaving the profession at a rate that has grown by more than $50 \%$ over the past 15 years. Each year $16.8 \%$ of our nation's teachers leave and in urban schools that number spikes to $20 \%$ as suggested by Dwyer, (2007). According to the recent policy brief published by the National Commission on Teaching and America's Future (NCTAF) estimated \$7.3 billion as the annual cost of teacher turnover in U.S. schools. Teacher quality and student achievement are at risk in this highturnover environment as well teachers who are new to the profession often find themselves frustrated, disappointed, and unsupported. In Uganda, the MoES 2014 report shows that 9\% or about 5,257 secondary school teachers in public schools quit work annually mainly due to poor pay, poor working conditions, limited promotional avenues and lack of motivation. Nsumba a Commissioner for Secondary School Education in Uganda says although some die, abscond or retire, a big number quit for better paying jobs in South Africa, Botswana, Rwanda or Kenya. The Commissioner added that, the exodus is mostly that of science teachers whom the Commissioner described as; "the best, selling like hot cake in the region and appreciated world over". This implies that a declined from 61,100 secondary school teachers in 2013 to 55,843 in 2014 has also caused a decline in the national student to teacher ratio, the persistent existence of ghost teachers, and loss of over 21 million shillings 
monthly by the government and over 252 million shillings annually if the shortage is not reported in time. In contrary Simola, (2005) averts that in Finnish society, the teaching profession has always enjoyed great public respect and appreciation. Parents trust teachers as professionals who know what is best for their children and teachers are generally committed to their students, enjoy their work, and are devoted to their profession and their content areas.

\subsection{Quality of Secondary Schooling}

Quality education refers to skills and knowledge that is potentially able to reflect the level of attainment. However, Inter-American Development Bank (IDB) 2000 report argued that the quality of secondary schooling throughout the African region is inadequate by international standards; teachers have inadequate subject knowledge, poor pedagogy and are often unmotivated; curriculum is encyclopedic and out of date; learning materials are scarce and inadequate; schools rarely have a sense of mission and identity; and school directors have little authority and recognition. In regards to the quality of secondary education, Asian countries have focused on curriculum reform that will more adequately prepare young people for the job market within the existing economic climate, while providing the human resources necessary to ensure sustainable national development, Byron cited in by Acedo, (2002). The reform and renewal of secondary school curricula is clearly a priority for all the countries. In Uganda the quality of education is affected because: the curriculum is theoretical with no employable skills gained after completion of secondary education; USE schools are money minded and they admit more students they can handle yet some of the schools lack adequate teachers; lack or have inadequate quality assurance services due to a combination of factors like shortage of quality assurance and standards officers, inadequate relevant training on quality assurance and shortage of resources such as motor cycles, vehicles and quality assurance units to for carrying out the work; difficulty attracting and retaining a skilled teaching workforce; difficulty providing a breadth of subjects and a range of education models to suit all learning types; and students are taught on how to pass examinations through comprehensive revision of examinations past papers and reading of pamphlets hence making them totally lazy to read text books, they duplicate what they have crammed form the pamphlet and they find it difficult to interpret and analyze the questions-poor performance and yet quality education is essential for achieving positive outcomes.

\subsection{Poor Quality of Teachers}

There is very little difference between trained and untrained teachers in preparation of teaching methods and use of teaching aids. Private schools employ more untrained teachers as compared to public schools. However, the performance of private schools is far better as compared to teachers in USE schools with trained teachers in Uganda. Tooley \& Dixon, (2005) study in India, Ghana and Nigeria found that children in low-cost private schools outperformed their peers in government schools, even when controlled for socio-economic and peer group effects. The poor performance is caused by poor recruitment to colleges or universities, poor hiring strategies, and inadequate training because of inadequate course content, difference/ poor curriculum for universities training teachers and lack of properly laid down teacher development programme. This assertion is supported by Uganda National Examination Board (UNEB) official report which contends that teachers have inadequate knowledge of Biology, English Language, Mathematics concepts and they lack ability to assess the learners. Reymick Oketch a former teacher of Kings College Buddo, adds that teachers don't know how to set tests, lack skills in marking, have no competencies to teach, and they lack content and ability to interpret concepts, (The New Vision, Thursday, April 23, 2015). This conforms well to UNEB report where they subjected teachers to the test questions before the learners could answer them. Interestingly, no teacher could pass the quiz on the sum of series and only $1.8 \%$ of the students passed. This implies that where teachers are lacking are the same areas where the learners are also lacking.

\subsection{High Teacher and Students' Absenteeism}

Several studies have been conducted on teacher and students' absenteeism. Chaudhury et al., (2006) study found that nearly one in five teachers were absent from their schools in Bangladesh, Ecuador, India, Indonesia, Peru, and Uganda. In India one quarter of teachers were absent and only 50\% actually engaged in the act of teaching while in Uganda the study shows an average rate of $27 \%$ teacher absenteeism. In contrary MoES: EMIS, 2014 report presents unacceptably high Head teacher, teachers' and learner absenteeism estimated at $20 \%$ on average, a primary teacher is estimated to be 
absent for at least 2 days a week. This implies that of the 55,270 secondary teachers in the FY2011/12 and 61,100 FY 2012/13 with 11.1\% increment; the government lost 9,301.6billion $(4,421.6 b i l i i o n$ in FY2011/12 and 4,880 billion in FY 2012/13) on teacher absenteeism in the last two financial years (that is over 4 billion shillings is lost annually by the Government through Ministry of Education and Sports on teacher absenteeism).

\begin{tabular}{|c|c|c|c|c|c|}
\hline Class & & 2011 & 2012 & 2013 & 2014 \\
\hline \multirow[b]{3}{*}{ Senior 1} & Male & 126,467 & 126,031 & 132,596 & 135,506 \\
\hline & Female & 110,115 & 109,897 & 118,444 & 118,077 \\
\hline & Total & 236,582 & 235,928 & 251,040 & 253,583 \\
\hline \multirow[b]{3}{*}{ Senior 2} & Male & 103,897 & 118,143 & 115,042 & 128,195 \\
\hline & Female & 89,836 & 101,311 & 100,308 & 113,421 \\
\hline & Total & 193,733 & 219,454 & 215,350 & 241,616 \\
\hline \multirow[b]{3}{*}{ Senior 3} & Male & 78,218 & 96,208 & 105,432 & 109,749 \\
\hline & Female & 63,043 & 80,345 & 88,756 & 94,838 \\
\hline & Total & 141,261 & $\mathbf{1 7 6 , 5 5 3}$ & 194,188 & 204,587 \\
\hline \multirow[b]{3}{*}{ Senior 4} & Male & 68,711 & 69,343 & 81,403 & 96,369 \\
\hline & Female & 49,254 & 52,739 & 65,011 & 77,321 \\
\hline & Total & 117,965 & 122,082 & 146,414 & 173,690 \\
\hline \multirow[b]{3}{*}{ Total } & Male & 377,293 & 409,725 & 434,473 & 469,819 \\
\hline & Female & 312,248 & 344,292 & 372,519 & 403,657 \\
\hline & Total & 689,541 & 754,017 & 808,992 & 873,476 \\
\hline \multirow[b]{3}{*}{ Senior 5} & Male & & 26,291 & 22,426 & 21,708 \\
\hline & Female & & 12,183 & 10,924 & 11,027 \\
\hline & Total & & 38,474 & 33,350 & 32,735 \\
\hline \multirow[b]{3}{*}{ Senior 6} & Male & & & 23,640 & 22,204 \\
\hline & Female & & & 10,961 & 10,870 \\
\hline & Total & & & 34,601 & 33,074 \\
\hline \multirow[b]{3}{*}{ Total } & Male & & 26,291 & 46,068 & 43,912 \\
\hline & Female & & 12,183 & 21,885 & 21,897 \\
\hline & Total & & 38,474 & 67,951 & 65,809 \\
\hline
\end{tabular}

Figure1.3.Shows USE Students Enrollment by Class \& Gender from 2011-2014 in Uganda

Source: MoES, EMIS, 2014

On the other hand student between 2011 and 2014 the students' dropout rate from the in dept analysis of the above data is at $13.6 \%$ while absenteeism is at rate of $23.2 \%$ respectively in Universal Secondary Education, (Komakech \& Osuu, 2014). This is equally causing the government to lose at least 9.2 billion shillings annually of tax payers and donor funds translating to about 27.6 billion shillings in the last three financial years (2011-2013). The implication of these to the sector includes; financial losses for the government and development partners, poor students performance, poor service delivery by the implementers, increased training costs and loss of key skills personnel, lower moral among teachers and learners, wastage of teachers' and administrators time, transfer of students by their parents/guardians to private schools, poor curriculum coverage, passing of half-baked students and increases chances of students dropout. However, a comparative study conducted by Tooley \& Dixon, (2005) on teacher activity in public and low-cost private schools in Ghana revealed that only $57 \%$ of government teachers were teaching when visited compared to about $70 \%$ of teachers in low-cost private schools; 67\% compared to $87 \%$ in Lagos, Nigeria, while $75 \%$ and $94 \%$ respectively in Hyderabad. These findings prompted parents to send their children to low private schools since they achieve better results than public schools, teachers can give learners more attention, class sizes are smaller, and proprietors are tough to general discipline of teachers and students. This situation is very similar to Uganda where parents have preferred private schools to public (USE) despite public schools being the most predominant in education service delivery but their performance have declined as compared to private schools.

\subsection{Teacher Strikes and Protests}

Strikes and threats of strikes are highly disruptive which cause parents to have challenging decisions of finding alternative schools for their children while students will also wonder whether teaching is a right profession to join because of the way teachers who are parents and mentors conduct themselves. For instance, in every financial year teachers are always the first group of employees to lament on the national budget whenever their demands are not covered in the budget forgetting the learners who are 
the purpose for their existence. This action shows the whole world that they are the poorest as indicated with frequent demonstration on streets at the expense of learners, shouting like mad people, showing bad examples to the children and having no respect to education values. According to Gindin, (2007) cited in by Bruns \& Luque, (2014) study shows that $60 \%$ of the strikes (disruptive actions) were aimed at improving teachers' economic conditions while $23 \%$ were related to other education policy issues. This is in contrary to Uganda case where over $97 \%$ of the strikes and demonstrations are on salaries and unions have not developed any proposal(s) or alternative proposal(s) for education reform; and they have left issues of education policies to politicians with no education background to gamble with. For instance in 2011 teachers were asking for $100 \%$ pay rise without considering the teachers shortages; provision of physical facilities such as classrooms, furniture, safe water source, teachers' accommodation, latrines, library, laboratories, installation of power, and resource centers and instructional materials like text books; students drop out and their own Ethical Code of Conduct for instance there is no single day Uganda National Teachers Union (UNATU); has come out to protest the conduct of their colleagues caught ready handed defiling the school girl but instead the shy and leave the matter to the police and the girl parent/guardian, help the government to track the Ghost teachers by availing teachers statistics, and hold non performing school head teachers and teachers responsible. In addition, on September 16, 2013 teachers countrywide under the umbrella of UNATU staged a strike as the third academic term was beginning in push for a $20 \%$ salary increment, the government instead offered a 50\% increment, which would be phased in three years that is; $15 \%$ in the first phase, $20 \%$ in the second and another $15 \%$ in the last segment. But, after the government failed to keep its promise for the second phase they went on strike without considering that $20 \%$ of their salary increment would translate into a wage bill of 139 billion shillings annually which the government could not find. This umbrella has also allied with opposition political parties in the country which look at $20 \%$ increment as very little money of about 50,000 shillings without looking at teachers' total number in the country.

\subsection{Difficulty in Access to Better Education}

Providing access to local, relevant and high quality education and training opportunities is critical to retaining rural students' participation and engagement in education, UNESCO, (2010). This target has not yet been achieved by the Government of Uganda. According to Komakech \& Osuu, (2014), the authors reveal that, some students still cover eight (8) kilo-meters daily on foot to reach their schools. The author noted that although these students access the school, their performance is affected by the time they spend in the morning and evening travelling to and from school; while $7.6 \%$ absent themselves because of long distance and female students are disturbed regularly by idle men. The MoES: EMIS, (2014) agrees that, there is no total access as not all children who should be in school are in school because of: inadequate level of capitation, leading to levies that parents cannot afford; delayed remittances of the grant, forcing school management to impose levies to purchase urgently needed learning materials at the beginning of each year; certain cultural practices like early marriages and tending to livestock forcing girls and boys out of school and inadequate infrastructural facilities especially lack of classrooms to accommodate all children. This report rhymes well with Komakech \& Osuu, (2014), study on students absenteeism which found that parents are feeling the pinch in the amount charged by school administration on uniform and development fund as a burden. The authors found that some schools are charging between Ush 85,000-135,000 on school uniform. Therefore, if these young people don't complete their studies, they become a burden to the society because of unemployment and poverty. Related to UNESCO, (2010) educational attainment is an important predictor of future health, employment and welfare prospects and plays an important role in tackling disadvantage. Young people who have gained an education are better able to participate in social, community and political life and make informed, balanced choices. Conversely, young people who have not completed a secondary education are almost four times more likely to report poor health, have mortality rates up to nine times higher than the general population and are more likely to require welfare support and government subsidized services.

\subsection{Gross Financial Mismanagement}

Despite the brilliant intention by the Ministry of Education and Sports to introduce public procurement in all public secondary schools so as to reduce corruption in public contracts, the sector is suffering from procurement personnel incompetence which is worst than corruption and has cause the government billions of money. According to the Public Procurement and Disposal of Public 
Assets Authority (PPDA) 2012 Audit Report reveals that; twelve (12) contracts amounting to UGX. $2,951,178,954$ were abandoned by contractors before completion, sixteen (16) contracts amounting to UGX. 4,179,983,504 had expired contracts before completion of the projects, five (5) projects with a total value of UGX.1,051,708,728 were not done satisfactorily and were in need of defects correction with the defects ranged from cracks on the floor/wall, wrong concrete mixtures, wrong timber dimensions and types, twelve (12) contracts amounting to UGX. 3,263,015,431 had expired performance securities and no extensions granted by contractors at the same time, the contractors had abandoned sites and schools had not enforced performance securities before their expiry, while three (3) contracts amounting to UGX. 622,320,490 were terminated due to lack of capacity and failure to perform as per the contract terms and conditions, and irregular change of contract scope from seven classrooms to nine amounting to UGX 207,114,300 as in the case of Inomo S.S in Apac district.

\subsection{Poor Deployment Strategies of Teachers}

Despite the fact that, transfer encourages employees to view the organization as one offering them career growth; there are serious challenges of teacher deployment. In Uganda, Head teachers, Board of Governors, PTA chairpersons often travel to the ministry to negotiate their teacher transfers and the ministry act without thorough investigation why such teacher should be transferred. These have contributed to increasing poor performance in many schools for instance Soroti Secondary School registered over 499 students in 2014 Uganda Certificate of Education (UCE) but only 12 students go first grade and the school was ranked $1316^{\text {th }}$ out of 2907 schools country wide as compared to its giant counter parts in Teso sub-region such as; Teso College Aloet with 99 in first grade out of 251 students and Ngora High School with 55 students in first grade out of 203 students with the country rank $102^{\text {th }}$ and $162^{\text {th }}$ positions respectively, (New Vision, Wednesday, February 04, 2015). Unplanned transfer of teachers was central to the gross performance decline. It is important to note that, teachers especially those transferred from first class schools to poor class schools irrespective of the type of transfer have got low morale to work hence poor performance. In addition, the ministry has also compromised the administrative performance of some head teachers who have initiated brilliant development plans and are transferred before the completion of their plans; some are transferred to areas which they don't want with the reason of language, distance from family, security of the area, in adequate social amenities such as accommodation, banking services, medical services, and limited opportunity to professional development among others; instead of the ministry to enforce the transfer decision they still give a listening ear and the head teacher or teacher freely decide on the new location and some even assure the ministry official if his/her request is not accepted s/he will resign and as a result the ministry department will compromise. Some excellent teachers are transferred to worst performing schools with views the that they can perform tremendously; in most cases they can perform better in new stations if other factors which may affect their performance are catered for. In case the teacher does not accept the transfer, this has a great effect on teachers' attendance especially where a teacher is posted far away from their family or their home area and as a result it will increase pressure to the teacher to take extended weekend breaks in order to visit home.

\section{Policy ImPlications/ReCOMmendations}

The following are the practical recommendations which are deemed fit for the Ministry of Education and Sports and other stakeholders in the education sector towards enhancing access, affordability and quality education in the country without financial implications on the sector budget.

\subsection{Introduce Open Schooling System to Increase Access and Enrolment}

The system refers to "the physical separation of the school level learner from the teacher, and the use of unconventional teaching methodologies, and information and communications technologies to bridge the separation and provide the education and training." The system has already been practiced in countries with access problems like South Africa, Namibia, and Botswana among other African countries. The system is found to be more economical because it cuts the cost of recruiting too many teachers, supervision, constructions drastically; provide opportunities to the school leavers, dropouts, working adults, housewives, and learners from distance and remote areas; reduce on the absenteeism level; and reach out to those who could not complete/continue their schooling due to socio-cultural and economic reasons. Rumble \& Koul, (2007) emphasized that even if one new secondary school were to be built every month for the next ten years, the increased demand will not be met, thus OS is the best answer to access. In practice, countries implementing OS programs have better access and 
high enrollment is secondary schools compared to the non-practicing countries. For instance the widespread expansion of this education level in all regions of the world between 1999 and 2009 increased the Gross Enrolment Ratio (GER) for lower secondary education from $72 \%$ to $80 \%$ globally. The most notable increase occurred in sub-Saharan Africa, where the GER for lower secondary education rose from $28 \%$ to $43 \%$. With only OS implementing countries (South Africa, Botswana, Seychelles, Mauritius and Namibia) in the sub- Saharan countries having ratios above $70 \%$ as compared to Uganda with 28\%, (Esi Sutherland-Addy, 2012; UNESCO, 2011).

\subsection{Increasing Expenditure is Not Enough}

A truism that needs to be underscored is that the availability of additional resources alone will not yield the expected gains, especially in respect of quality, unless existing weaknesses both in educational management and the teaching learning process are seriously addressed and remedied. While chronic under resourcing of the system is a generic problem that spawns many other problems, everything cannot be solved with additional funds. Along with effective management of resources, decision-making and implementation of decisions regarding learning objectives, the pedagogic process and establishing accountability at all levels have to be improved.

\subsection{Reducing School Failure}

Whereas successful secondary education completion gives individuals better employment and healthier lifestyle prospects resulting in greater contributions to public budgets and investment; the researcher recommends the Ministry of Education and Sports to allow failed students to repeat only the failed papers instead of repeating the all year. This will improve on their grades, boost retention and promotion to the next level of education. To greater extent, the compulsory subjects such as; English, mathematics, physics, chemistry, and biology are most failed papers as compared to electives subjects such as; commerce, agriculture, computer, history, geography, politics, English literature, music, fine art and Kiswahili among others. The researcher explained that after the student has passed the repeated paper(s) the results should be posted in the certificate and should cancel the results in the first sitting. This will reduce the level of drop outs at the same time it will make the student concentrate to understand the subject since s/he did not understand in the first time and increases the chance of the student to obtain a better grade and take better course.

\subsection{Computerized Selection System}

In order to encourage the balance between rural and urban schools; the researcher recommends computerized system of selecting students to senior one and five. These will cut costs and saves time as compared to the manual system where teachers gather in Namboole for over two days doing selection. The system will enhance transparency and fairness in student's selection and will solve the allegations of some high performing schools of being biased on students from other schools. In this regard, students should be given three choices for particular schools they wish to attend and also fill out the district they would want to attend school in as their fourth choice. The system will be demand driven since the points required will be dependent on the number of places available and the number of candidates applying to a particular school. However, the short list will be published in the national news paper, ministry website, and students can also check their names in district education office notice board. In case a student failed to be admitted in the schools selected, s/he can reply to at a fee to the school s/he feels can admit best on the points. In addition, students which will accept to study in rural schools should be given double chance opportunity to benefit from the scholarship and development programmes.

\subsection{Reduce Teachers Absenteeism}

Teacher absenteeism for this study refers to failure of an employee to report for or to remain at work as scheduled, regardless of the reason. In Uganda, teacher absenteeism is strongly related to the frequency of monitoring, location of the school, distance to the road and distance to government education offices. Thus teacher absenteeism can be reduced through enforcement of applicable sanctions toward teachers who do not fulfill their duties; monitor teacher attendance rates on a regular basis, involving communities; improve the quality and availability of teacher housing facilities; and monitor teacher's attendance by Camera. In India Duflo \& Henna, (2006) evaluate a randomized intervention in community schools in which an NGO provides cameras to teachers and institutes attendance-dependent remuneration where teachers were expected to take pictures every morning and 
are paid depending on the number of full days attended. The results of this intervention were surprisingly large in that teacher absence fell by about half from a high of $36 \%$ in comparison schools to $18 \%$ in treatment schools. The researcher recommends the similar practice to be piloted in at least fifteen districts and teacher's photos be taken in the morning (8:30am); during the time a teacher is conducting a lesion and in the afternoon $(3: 30 \mathrm{pm})$ at the same time they should sign an attendance book.

\subsection{Zero Tolerance to Student Absenteeism}

The Ministry should put strict policy of "Zero Tolerance To Student Absenteeism" across the country in order to address the current students' absenteeism of $23.2 \%$ and the escalating annual dropout of over $10 \%$ USE schools' students in Uganda. This will reduce on teachers' absenteeism, improve the quality of education, save the tax payers money, enhance the student's performance, and improve on school's reputation and ranking. Furthermore, the policy must make sure that children are enrolled and attend schools on all school days unless there is a reasonable excuse; in that case schools are mandated to monitor attendance of students and follow up with parents/guardians any unexplained absences.

\subsection{Extend the Loan Scheme/Scholarships to Education Courses}

Vegas \& Umansky, (2005) study confirms that individuals are attracted to the teaching profession and inspired to high performance for a variety of reasons: professional rewards including intrinsic satisfaction, recognition and prestige, professional growth, intellectual mastery, and pleasant working conditions; accountability pressure which encompasses feedback from parents and students, peers, and supervisors, as well as the threat of demotion or dismissal; and financial incentives such as salary level, pensions and other benefits like bonus pay. Therefore in order to attract academically stronger candidates into teacher education there is need by the government through the MoES to initiate scholarships for high performing students who choose teaching. The scholarship should cover tuition fees, accommodation, and meals. This approach will attract high talented individuals in the profession as compared to the current situation where education course is look as a last resort and it is full of low performers or failed students at either ' $O$ ' level or 'A' level.

\subsection{Increase the Years of Teacher Trainees}

In order to improve the performance of secondary education and the whole system in Uganda, the researcher appeal to the Government of Uganda through the Ministry of Education and Sports to increase the number of years teacher trainees spend in colleges. This is because the quality of primary education has a long term effect on child academic growth. The 7-4-2 system where a child joins primary one at 6 years and completes Grade III Certificate at 18 years and joins the public service in the following year after which s/he begins to demand for 1 million salary pay or $100 \%$ salary increment. In this case, a child is "teaching a child" which value addition is she/he imparting on other children? It is against this background the researcher recommends the government to increase the number of years teacher spends on Primary Teachers' Colleges (PTC) to three (3) years from two (2) with one mandatory year in practical teaching in government school before joining public service. These will lead to award of Diploma in Primary Education and such teachers when recruited should be given temporal appointment letters until they obtain a bachelors' degree that is when they can be offered a permanent appointment for teaching. For the case of secondary teachers, degree is ideal for temporal appointment and masters' degree for a permanent teaching job. These approaches will produce graduates for 2030 which are dynamic, flexible and will solve Uganda's problems of high dependency syndrome. For instance the possession of a master's degree in education not only qualifies someone to teach school but opens the door to employment in public administration or in the private sector.

\subsection{Recruiting UNATU Competent Leaders in Key Government Education Structure}

To reduce pressure teachers' union the government should appoint some of the competent union leaders in key government positions. This will allow the union to maintain high levels of discipline among its members because teachers will fear to disagree with their union leadership for the fear of being fired, denied access to favorable benefits, or being sent to remote locations far from where they live as a punishment. In countries like Paraguay, Costa Rica and Uruguay the teachers' unions have strong influence over the operation of the education sector, the union has increased the level of 
Using Zero Money to Tackle the Challenges of Universal Education in Africa: A Case of Universal Secondary Education in Uganda

teacher participation in committees that evaluate, select technical, pedagogical issues and administrative staff.

\subsection{Training the Procurement and Disposal Unit (PDU) Staff}

The Head Teachers (Accounting Officers) should ensure that the Contract Management Team has the qualification, knowledge and experience required in order to manage the contract effectively. The roles involved in the management of a contract and their competencies must be clearly specified. The officials who will be called upon to serve these roles must have been selected using objective criteria in order to ensure that they have the necessary technical knowledge, and have skills such as; communication and analytical skills, cooperation skills, negotiation skills, financial and management skills, and possession of planning skills are necessary for public secondary schools procurement units in Uganda. The staff in the PDUs should undergo intensive capacity building training and development by PPDA or procurement professional body (Institute of Public Procurement in Uganda) in order to improve on competence and depth understanding of procurement principles such as; principles of integrity, transparency, accountability, fairness, and efficiency throughout the procurement process so as to minimize corruption risks and maximize the chance that the economic, social, environmental and political benefits of public procurement will be realized. In addition, the researcher recommends that the Ministry of Education should recruit at least a procurement officer for each unit/ one at the district to handle schools procurement.

\subsection{Early Notification of Teachers on Transfer}

The researcher recommends that the ministry should publish the transfer list three or four months earlier to allow the staff sufficient time to prepare for the next station and since it comes before the closer of the year; the teacher will have time to say farewell to the school management, students and fellow collogues other than the management being taken un aware. In case, of fear that the teacher will misbehave, the supervisor should keep close monitoring and caution the him/her on the implication since the service of the staff is not yet terminated from the school thus the supervisor will appraise and should send a copy of the appraisal report to where the staff has been redeployed in order for prospective supervisor to have prior knowledge about the incoming staff. In addition, the ministry should classify its entire staff according to teaching subjects so as to avoid replacing staff with different teaching subject as a result the school will end up having surplus teachers in other subjects while shortage in others and yet the staff has met the ceiling. Therefore, early dissemination of the list will help school administration to rectify the problem earlier other than waiting when students have reported and during allocation that is when the gap will be realized. The school management (BOGs and PTA) committee should be given authority to approve or disapprove teacher transfers other than taking the head teacher's recommendation who is also transferable. In addition, the ministry should stand with its decision without giving a hearing room for staff not willing to report to the new station to reduce administrative costs and time.

\subsection{Governance and Management of Secondary Education}

It is important to note that, all of the weaknesses and deficiencies in secondary education such as; the pedagogic process, resources and inputs, access and participation issues, teaching personnel, curricula and learning materials are all attributed ultimately to governance and management of the system. Therefore, other than managing the sector through regulations and practices based on tradition, custom and precedence rather than responsiveness to changing needs and conditions from hundreds of kilometers; the researcher recommends that the administration of secondary education be decentralized to regional and district levels. This will ease the monitoring of teachers and schools address the excessive centralized and bureaucratic control of the system and poor internal efficiency throughout the system. This will also improve on results in the classroom and learning outcomes since the regional and district supervisors will keep their toes on the ground and as ministry will demand regular updates from them.

\subsection{Teacher Deployment}

Other than teacher transfer, teacher deployment has also hampered the efficiency and quality of education delivery. In relation to this, the researcher recommends urgent need to find a credible and scientific means to enable the ministry to ascertain the actual number of teachers needed in each district and come out with realistic vacancies in the districts since there is high variation of enrolment 
between schools and districts. This will solve the political criticism of unbalanced distribution of teachers in the country. For instance, MoES, (2010) statistics shows the regional placement of teachers in 2010 as; $38.5 \%$ of all teachers were assigned to Central region, $24.0 \%$ to East region, $15.2 \%$ to Southwest region, $11.6 \%$ to North region and $10.1 \%$ to West region. Northeast region had the lowest number of students in secondary education at 10,221 ( $0.80 \%$ of the national total), while its number of teachers was just 423 ( $0.7 \%$ of the total). This distribution is imbalance because there schools in the region which has over 120 teaching staff and being traditional schools priority is given in order to maintain their status.

\subsection{Expand the Double Shifts Systems}

Expanding the double shifts system in urban and selected rural areas will reduce the gap in facilities between urban and rural secondary schools; will lower late coming since the student will have ample time to work to school, enhance completion of assignment(s) by students as a result it will reduces the students' absenteeism rate since some students dodge or absent themselves because of failure to complete the teachers' assignments; and will contain the country's $50 \%$ estimated proportion of young children (age 0-14 years) attributed to $3.5 \%$ estimated population growth rate. Contributing to the same debate, Rumble \& Koul, (2007) emphasized that even if one new secondary school were to be built every month for the next ten years, the increased demand will not be met, thus Double Shifts Systems is the immediate solution to access.

\section{Conclusion}

The secondary education sub-sector since 2013 has continued to prioritize efficiency (is the extent to which an activity achieves its goal while minimizing resource usage) and effective (is the extent to which the activity fulfils its intended purpose or function) measure in the delivery of secondary education in the country (through the implementation of interventions that enhances efficiency and effectiveness such as; training of members of school construction, management, procurement and contracts committees; appointment and constitution of new BOG'S; capacity building and orientation of newly appointed bogs members; monitoring and support supervision; facilitated the USE national headcount exercise; and training head teachers and deputy head teachers on better resource allocation efficiency measures in light of constrained funding) instead of focusing on outcomes that encompasses knowledge, skills and attitudes to national goals for education. The education system performance should also be seen in the context of other systems in the society such as health, environment, rule of law, governance, economy, and technology. The government should reduce spending on wrong people (ghost teachers) by reconciling the pay roll with updated teachers' data. Building a culture of lifelong learning by acknowledging that if teacher standards at the point of recruitment are not selective, then investments in higher salaries are wasted and teacher professionalism will not rise. The MoES should have sustainable and stable education policies rather than conflicting policies which are directed to political interests. The ministry should develop uniform curriculum for all universities education programmes, close low quality universities and colleges, establish a national teacher university directly controlled by the ministry, and work in conjunction with the National Council of Higher (NCHE) to raise accreditation standards for universities based programmes. Strengthen and improve educational planning and management roles and responsibilities for centralized and decentralized departments as well as schools and institutions in implementing policy and strategies. Finally, apart from overcrowded classrooms, inadequate physical facilities, and scarce learning materials, the recruitment and remuneration system of teachers attract poor academic performers into teaching.

\section{REFERENCES}

[1] Acedo, C., (2002). Case Studies in Secondary Education Reform. IEQ undertaken by: American Institutes for Research. The University of Pittsburgh.

[2] Bruns, B., \& Luque, J., (2014). Great Teachers: How to Raise Student Learning in Latin America and the Caribbean. Washington DC 20433: World Bank. Available at: www. worldbank.org

[3] Chaudhury, N., Hammer, J., Kremer, M., Muralidharan, K., \& Rogers. F.H., (2006). "Missing in Action: Teacher and Health Worker Absence in Developing Countries." Journal of Economic Perspectives 
Using Zero Money to Tackle the Challenges of Universal Education in Africa: A Case of Universal Secondary Education in Uganda

[4] Duflo, E. \& Henna, R., (2006). "Monitoring Works: Getting Teachers to Come to School" Mimeo MIT. Inter-American Development Bank (IDB). (2000). Reforming primary and secondary education in Latin America and the Caribbean: An IDB strategy.

[5] Dwyer, C.A., (2007). America's Challenge: Effective Teachers for At-Risk Schools and Students. National Comprehensive Center for Teacher Quality.

[6] Esi Sutherland-Addy, (2014). Gender Equity in Junior and Senior Secondary Education in SubSaharan Africa. Africa Region Human Development Department: The World Bank Washington D.C.

[7] Gindin, J., (2007). La Conflictividad Docenteen América Latina: Un Balance delaño 2004. Buenos Aires: Laboratorio de Políticas Públicas.

[8] IDB, (2000). Reforming primary and secondary education in Latin America and the Caribbean: An Inter America Development Bank (IDB) strategy.

[9] Komakech R.A. \& Osuu, J.R., (2014). STUDENTS' ABSENTEEISM: A Silent Killer of Universal Secondary Education (USE) in Uganda. International Journal of Education and Research, Vol. 2 No. 10 October, 2014; PP 417-436

[10] Ministry of Education and Sports, (2001): The Development of Education in Uganda in the Last Ten Years. Report on the Development of Education for the $46^{\text {th }}$ Session of $5^{\text {th }}$ to $7^{\text {th }}$ September 2001,Geneva;Retrieved on November 08, 2014 at www.ibe.unesco.org/International/ICE/ natrap/Uganda.pdf

[11] Ministry of Education and Sport: Education Management Information System, (2014). Government of the Republic of Uganda

[12] Ministry of Education \& Sports (MoES): Education and Sports Sector Annual Performance Report, (2013). Government of the Republic of Uganda

[13] Ministry of Education and Sports, (1999). The Ugandan Experience of Universal Primary Education. Government of the Republic of Uganda.

[14] Ministry of Education and Sports, (1992). Government White Paper on the Education Policy Review Commission. Government of the Republic of Uganda.

[15] Rumble, G. \& Koul. B.N., (2007). Open Schooling for Secondary \& Higher Secondary Education: Costs and Effectiveness in India and Namibia. Commonwealth of Learning (COL): Vancouver, BC

[16] Simola, H. (2005). The Finnish Miracle of PISA: Historical and Sociological Remarks on Teaching and Teacher Education. Comparative Education, 41(4), 455-470.

[17] Tooley, J. \& Dixon, P, (2005). Private Education Is Good for the Poor: A Study of Private Schools Serving the Poor in Low-income Countries. Washington, D.C.: Cato Institute.

[18] UNESCO, (2011). Global Education Digest 2011Regional Profile: Sub-Saharan Africa. UNESCO Institute for Statistics. Available at http://www.uis.unesco.org/Education/ Documents /.pdf

[19] UNESCO, (2010). Reaching the Marginalized: EFA Global Monitoring Report. Rep. Oxford: Oxford Education for All.

[20] Vegas, E., \& Umansky. I., (2005). "Improving Teaching and Learning through Effective Incentives." In Incentives to Improve Teaching: Lessons from Latin America. In Vegas, E.,(Ed). Washington, DC: World Bank.

[21] World Bank, (2008). Teachers for rural schools : Experiences in Lesotho, Malawi, Mozambique, Tanzania, and Uganda. In Mulkeen, A., \& Chen, D. (Eds). Africa Human Dvelopment Series. Available at: http://siteresources.worldbank.org/ EDTeachers ruralschools LMMTU.pdf

[22] World Bank, (2002). India: Secondary education and the New Agenda for Economic Growth. Washington DC: Report No. 24208-IN. The World Bank. 


\section{Definitions of Key Words}

Zero Money: It sounds appealing to many by saying using Zero Money to tackle the challenges of education in Africa. Zero Money therefore, means using non-financial interventions (such as good management practice, spending on right goods and people, employing competent personnel, reduce corruption such as teachers absenteeism, students absenteeism, need to move towards private forms of secondary education because of demographic growth and financial constraints, and have vision driven education) to solve the challenges in the education sector

Universal Education: Refers to Education For All (EFA) while EFA refers to the provision of basic education for all children, youth and adults. It was launched at the World Conference on Education for All in 1990.

Secondary Education: Is critical stage of the education system that links initial education to higher education and connect the school system to the labour market.

Quality Education: Refers to skills and knowledge that is potentially able to reflect the level of attainment.

Ghost Teachers: Refers to teachers who do not hold a teaching position but who are on the payroll and continue to receive pay, which may be cashed by other officials.

\section{AUTHOR'S BIOGRAPHY}

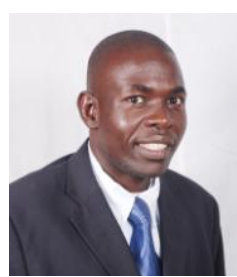

Robert Agwot Komakech, is the Fieldwork Coordinator and Head of Department, Business Studies-Kumi University. He is a Procurement \& Logistics specialist with over 08 years of progressive teaching experience at Secondary School and University level mainly for undergraduate programmes. Komakech is internationally exposed and has travelled in more than 06 countries. His research interests are in areas of Public Procurement, Supply Chain Management, Education and Policy Planning, and Public Sector Reforms. He has made a number of paper presentations at local and international workshops and conferences; and has published in Local and International referred Journals within his areas of academic competence and research interest. He is well known for his professionalism, transparency and integrity with his excellent ability to communicate knowledge, team work as well as providing counseling and career guidance to students. 